\title{
PENYELESIAAN SENGKETA KONTRAK KONSTRUKSI PADA PROYEK PEMERINTAH YANG MENCANTUMKAN KLAUSULA ARBITRASE
}

\author{
Beri Yandie* \\ CV. Bergin Dwi Dimensi
}

\begin{abstract}
Arbitration is an alternative mechanism to settle a construction dispute outside the court based on a Construction Work Contract by using an Arbitration clause made in writing by the parties to the dispute. Arbitration is much in demand in handling disputes over construction work contracts because it is believed to be more effective and efficient. The purpose of this research is to discuss the legal consequences of inserting the Arbitration Clause in a construction work contract under Law No. 2 of 2017 concerning Construction Services in the State Gazette of the Republic of Indonesia Number 11 and Additional State Gazette of the Republic of Indonesia Number 6018 in lieu of Law No. 18 of 1999 concerning Construction Services in theState Gazette Number 54 and Additional State Gazette Number 3833. In addition, it aims to analyze the dispute resolution process in a construction contract based on Law No. 30 of 1999 concerning Arbitration and ADR. It uses a normative legal research with a qualitative approach to analize the collected data. It finds that the legal consequences of the inclusion of arbitration clauses in construction work contracts is that the dispute issue through arbitration. Article 70 of Law No.30 of 1999 may be used by the parties to a request for cancellation of the arbitration award at the State Court. Construction work contracts are the domain of private law.
\end{abstract}

Keywords: Construction work contracts, arbitration clause, construction diputes.

\begin{abstract}
Abstrak
Arbitrase merupakan mekanisme alternatif untuk penyelesaian sebuah sengketa konstruksi di luar pengadilan yang didasarkan pada suatu kontrak kerja konstruksi menggunakan klausa Arbitrase yang dibuat secara tertulis oleh para pihak yang bersengketa. Arbitrase banyak diminati dalam menangani sengketa kontrak kerja konstruksi dikarenakan diyakini lebih efektif dan efisien. Tujuan penelitian ini untuk membahas konsekuensi hukum penerapan klausa arbitrase dalam suatu kontrak kerja konstruksi apabila terjadi sengketa menurut UndangUndang No. 2 Tahun 2017 Tentang Jasa Konstruksi Lembaran Negara Republik Indonesia Nomor 11 dan Tambahan Lembaran Negara Republik Indonesia Nomor 6018 sebagai pengganti UU No. 18 Tahun 1999 tentang Jasa Konstruksi Lembaran Negara Nomor 54 dan Tambahan Lembaran Negara Nomor 3833. Selain itu, penelitian ini bertujuan menganalisis proses penyelesaian sengketa dalam kontrak konstruksi berdasarkan Undang-undang No. 30 Tahun 1999 Tentang Arbitrase dan APS. Penelitian ini merupakan penelitian hukum normative yang menggunakan pendekatan kualitatif untuk menganalis data yang
\end{abstract}

*Alamat Korespondensi : b3r1_st@yahoo.co.id 
terkumpul. Penelitian menyatakan bahawa akibat hukum pencantuman klausa arbitrase dalam kontrak kerja konstruksi adalah penyelesaian sengketa harus melalui arbitrase. Pasal 70 boleh digunakan bagi para pihak untuk mengajukan permohonan pembatalan terhadap putusan arbitrase pada Pengadilan Negeri. Kontrak kerja konstruksi merupakan ranah hukum privat, yaitu ranah hukum perdata.

\section{Kata Kunci : Kontrak kerja konstruksi, klausula arbitrase, sengketa konstruksi.}

\section{A. Latar Belakag Masalah}

Pelaksanaan pembangunan Kontruksi di bidang usaha jasa konstruksi ${ }^{1}$ banyak melibatkan SDA, SDM, yaitu material, energi dan elektrikal dan mekanikal, SDA materil. Pada proses pelaksanaan ini dibuat dan sudah ditetepkan serta sudah diatur sehingga pekerjaan sesuai dengan waktu pelaksanaan dan berjalan sesuai dengan rencana.

Dalam setiap proses pelaksanaan ada juga yang mengalami rintangan antara lain dari faktor sumber daya dan manusianya. Rintangan - rintangan tersebut harus di cegah dan di selesaikan dengan baik untuk mengurangi kerugian, apakah itu dari waktu pelaksanaan maupun biaya operasional bangunan nanti. Maka dari itu penelitian ini membahas tentang sengketa yang terjadi pada kontrak kerja konstruksi dan bagaimana cara penyelesaiannya, yang terdapat di dalam literatur ( baik aturan maupun doktrin hukum ) maupun dalam pelaksanaannya khususnya untuk proyek skala kecil hingga menengah.

Maka dibutuhkanlah suatu solusi lain untuk jalan keluar permasalahan perselisihan sengketa konstruksi. Cara metode jalan keluar permasalahan perselisihan di luar mahkamah ( Non Litigasi ) biasa dikatakan dengan Alternatif Penyelesaian Sengketa (APS). APS ialah sebuah alternatif upaya jalan keluar perselisihan yang dilakukan di luar mahkamah. Istilah APS ini sama dengan istilah ADR ( Alternative Disputes Resolution ). Ada beberapa macam yang terdapat didalam APS antara lain jalur negosiasi, jalur mediasi, jalur konsultasi, jalur konsiliasi, dan jalur penilaian ahli. Sebagaimana yang tertuang di dalam Pasal 1 ayat ( 10 ) UU No. 30 / 1999 mengenai arbitrase dan APS.

\section{B. Perumusan Masalah}

1. Apa konsekuensi kontrak kerja konstruksi pada proyek pemerintah yang mencantumkan klausa arbitrase?

2. Apakah putusan arbitrase pada kontrak konstruksi proyek pemerintah dapat dibatalkan oleh Pengadilan Negeri?

3. Bagaimana apabila sengketa kontrak kerja konstruksi mempunyai unsur pidana menurut Pihak Ketiga, sedangkan dalam pandangan Para Pihak masuk dalam kategori kontrak atau ranah perdata?

\footnotetext{
${ }^{1}$ http://www.pengadaan.web.id/2016/10/pengertian-dan-jenis-usaha-jasa-onstruksi.html, tanggal 16 Mei 2017
} 


\section{Metode Penelitian}

Untuk memecahkan isu hukum sekaligus memberikan preskripsi atas apa yang seyogyanya, diperlukan sumber-sumber penelitian berupa data sekunder, yang terdiri dari tiga bahan hukum, yaitu bahan hukum primer, bahan hukum sekunder, dan bahan hukum tersier dengan rincian sebagai berikut (1) : bahan hukum primer, yaitu bahan hukum yang bersifat otoritatif. Artinya bahan hukum itu mempunyai otoritas seperti perundang-undangan, catatan-catatan resmi atau risalah dalam pembuatan perundang-undangan, dan putusan-putusan hakim. $^{2}$ Definisi peraturan perundang-undangan menurut Pasal 1 angka 2 Undang-undang Nomor 12 Tahun 2011 tentang Pembentukan Peraturan Perundang - undangan adalah peraturan tertulis yang memuat norma hukum yang mengikat secara umum dan dibentuk atau ditetapkan oleh lembaga negara atau pejabat yang berwenang melalui prosedur yang ditetapkan dalam peraturan perundang-undangan. Dari pengertian itu maka bahan hukum primer juga termasuk legislasi dan regulasi. Menurut Peter, beschikking / decree misalnya Keputusan Presiden, Keputusan Menteri, Keputusan Bupati, keputusan suatu badan tertentu bukan peraturan perundang-undangan sesuai dengan apa yang telah diatur dalam UU No 10 tahun 2004 tersebut. ${ }^{3}$ Bahkan biasanya, beschikking / decree tersebut menjadi objek gugatan di peradilan Tata Usaha Negara atau menjadi objek yang diteliti secara akademis; (2) bahan-bahan hukum sekunder berupa semua publikasi tentang hukum yang bukan merupakan dokumen-dokumen resmi. Publikasi tentang hukum meliputi buku-buku teks, jurnal-jurnal hukum, dan komentar-komentar atas putusan pengadilan sebagai pendapat ahli-ahli hukum; (3) bahan hukum tersier berupa kamus-kamus hukum.

Adapun pendekatan dalam penelitian ini yang digunakan yaitu: (1) pendekatan undang-undang atau "statute approach" dilakukan dengan menelaah semua undang-undang dan regulasi yang bersangkut paut dengan isu hukum yang ditangani. Dalam penelitian untuk kegiatan akademis, peneliti perlu mencari ratio-legis dan dasar ontologis lahirnya undang-undang tersebut sehingga digarapkan peneliti dapat menangkap kandungan filosofi yang ada di belakang undang-undang itu yang akhirnya dapat menyimpulkan ada tidaknya benturan filosofis antara undang-undang dengan isu hukum yang dihadapi. ${ }^{4}$ pendekatan kasus atau "case approach" dilakukan dengan cara melakukan telaah terhadap kasus-kasus yang berkaitan dengan isu hukum yang dihadapi yang telah menjadi putusan pengadilan dan telah mempunyai kekuatan hukum tetap. (3) pendekatan historis atau "historical approach" dilakukan dengan menelaah latar belakang apa yang dipelajari dan perkembangan pengaturan atas

\footnotetext{
${ }^{2}$ Peter Mahmud Marzuki, Penelitian Hukum, Kencana, Jakarta,: 2007, hlm. 181

${ }^{3}$ Peter Mahmud Marzuki, Penelitian Hukum, Jakarta: Prenada Media Group, Cetakan ke-6, Februari 2010, hlm. 93

${ }^{4}$ Peter Mahmud Marzuki, Penelitian Hukum, Jakarta: Prenada Media Group, Cetakan ke-6, Februari 2010, hlm. 94

${ }^{5}$ Ibid.,
} 
isu hukum yang dihadapi. ${ }^{6}$ (4) pendekatan konseptual atau "conceptual approach" pendekatannya beranjak dari pandangan-pandangan dan doktrindoktrin yang berkembang di dalam ilmu hukum sehingga diharapkan peneliti akan menemukan ide-ide yang melahirkan pengertian-pengertian hukum, konsep-konsep hukum, dan asas-asas hukum yang relevan dengan isu yang dihadapi. Pemahaman akan doktrin-doktrin dan pandangan-pandangan itu merupakan sandaran bagi peneliti dalam membangun suatu argumentasi hukum dalam memecahkan isu hukum yang dihadapi.

Seperti disebutkan di atas maka penelitian ini menggunakan metode analisis yuridis kualitatif dengan dua pendekatan yaitu undang-undang dan konseptual. Penelitian akan banyak mengambil kutipan dari Studi Keputakaan dan Studi dokumen dalam upaya untuk tetap memberikan arti yang sebenarnya-benarnya dan dapat segera langsung diberikan komentar oleh pembaca bila diindikasikan ada penafsiran yang lain dari yang dipahami oleh peneliti. Gambar dan tabel langsung dimasukkan ke dalam masing-masing bab yang bersesuaian dengan tujuan.

Data yang diperoleh dalam penelitian ini dianalisis secara yuridis kualitatif dengan menggunakan metode berpikir deduktif (umum-khusus), yaitu dengan menjabarkan, menafsirkan dan mengkonstruksikan data yang diperoleh berdasarkan norma-norma atau kaidah-kaidah, teori-teori, pengertian-pengertian hukum dan doktrin-doktrin yang ada dalam dokumen, Peraturan Perundangundangan, untuk menjawab permasalahan yang ada. Analisis data dilakukan secara bertahap, sehingga kekurangan data penelitian secepatnya dapat diketahui dan sesegera mungkin dilengkapi dengan melakukan penelitian ulang guna pengambilan data tambahan untuk melengkapi kekuarangan data tersebut.

\section{Hasil Penelitian dan Pembahasan}

\section{Konsekuensi kontrak kerja konstruksi pada proyek pemerintah yang mencantumkan klausa arbitrase}

Didalam Undang - undang Republik Indonesi "Nomor 2 Tahun 2017 Tentang Jasa Konstruksi" pada Bab IV Usaha Jasa Konstruksi dan "Pasal 12 Jenis Usaha Jasa Konstruksi" meliputi: ${ }^{7}$

a. Usaha Jasa Pelayanan Konsultansi

b. Usaha Pekerjaan Pelaksana Konstruksi

c. Usaha Pekerjaan Pelaksana Konstruksi Terintegrasi

Segmentasi Pasar Jasa Konstruksi Pada Pasal 24 untuk pelaksanaan jasa konstruksi yang memakai APBD dan berkriteria berisiko kecil dan sedang, mempunyai teknologi yang sederhana hingga sedang, serta biaya yang kecil hingga biaya sedang, Pemerintah Provinsi bisa membuat kebijakkan Khusus, Kebijakkan Khusus yang dimaksud terdapat pada ayat 1 yaitu :

\footnotetext{
${ }^{6}$ Ibid.,

${ }^{7}$ Undang - undang No. 2 Tahun 2017, Bab IV, Usaha Jasa Konstruksi
} 
a. KSO dengan badan usaha jasa konstruksi.

b. Penggunaan Subpenyedia Jasa.

Penyelesaian Sengketa yang terjadi pada Kontrak Konstruksi diselesaikan sesuai dengan ketentuan Pasal 88 Undang - Undang Jasa Konstruksi Nomor 2 Tahun $2017^{8}$ :

1. Permasalahan sengketa yang terjadi di dalam Kontrak Kerja Konstruksi bagunya diselesaikan dengan prinsip dasar musyawarah untuk mencapai mufakat.

2. Untuk musyawarah para pihak yang terdapat didalam ayat 1 tidak dapat mencapai suatu kemufakatan, para pihak menempuh tahapan upaya penyelesaian sengketa yang tercantum dalam Kontrak Kerja Konstruksi.

3. Dalam hal upaya penyelesaian sengketa tidak tercantum dalam Kontrak Kerja Konstruksi sebagaimana dimaksud pada ayat (2), para pihak yang bersengketa membuat suatu persetujuan tertulis mengenai tata cara penyelesaian sengketa yang akan dipilih.

4. Tahapan upaya penyelesaian sengketa sebagaimana dimaksud pada ayat (2) meliputi:
a. mediasi;
b. konsiliasi; dan
c. arbitrase

5. Selain upaya penyelesaian sengketa sebagaimana dimaksud pada ayat (4) huruf a dan huruf b, para pihak dapat membentuk dewan sengketa.

6. Dalam hal upaya penyelesaian sengketa dilakukan dengan membentuk dewan sengketa sebagaimana dimaksud pada ayat (5), pemilihan keanggotaan dewan sengketa dilaksanakan berdasarkan prinsip profesionalitas dan tidak menjadi bagian dari salah satu pihak.

7. Ketentuan lebih lanjut mengenai penyelesaian sengketa sebagaimanadimaksud pada ayat (1) diatur dalam Peraturan Pemerintah.

Selanjutnya, mengenai berlakunya Kontrak Kerja Konstruksi (Kontrak Pengadaan Jasa Konstruksi) sebagaimana menurut ketentuan Pasal 46 Undang-Undang Republik Indonesia Nomor 2 Tahun 2017 tentang Jasa Konstruksi yang menentukan bahwa:

1. Pengaturan hubungan kerja antara Pengguna Jasa dan Penyedia Jasa harus dituangkan ke dalam Kontrak kerja Konstruksi;

2. Bentuk Kontrak Kerja Konstruksi dapat mengikuti perkembangan kebutuhan dan dilaksanakan sesuai dengan peraturan perundang-undangan yang berlaku.

${ }^{8}$ Undang - undang No. 2 Tahun 2017, Bab XI, Penyelesaian Sengketa Jasa Konstruksi 
Pasal 47 ayat (1) Undang-Undang Republik Indonesia Nomor 2 Tahun 2017 tentang Jasa Konstruksi menentukan bahwa Kontrak Kerja Konstruksi paling sedikit harus mencakup uraian mengenai:

$>$ Para pihak, memuat secara jelas identitas para pihak

$>$ Rumusan pekerjaan, memuat uraian yang jelas dan rinci tentang lingkup kerja, nilai pekerjaan, harga satuan, lumsum, dan batasan waktu pekerjaan

> Masa pertanggungan, memuat tentang jangka waktu pelaksanaan dan pemeliharaan yang menjadi tanggung jawab Penyedia Jasa

> Hak dan kewajiban yang setara, memuat hak Pengguna Jasa untuk memperoleh hasil Jasa Konstruksi dan kewajibannya untuk memenuhi ketentuan yang diperjanjikan, serta hak Penyedia Jasa untuk memperoleh informasi dan imbalan jasa serta kewajibannya melaksanakan jasa konstruksi

> Penggunaan tenaga kerja konstruksi, memuat kewajiban mempekerjakan tenaga kerja konstruksi yang bersertifikat

$>$ Cara pembayaran, memuat ketentuan tentang kewajiban Pengguna Jasa dalam melakukan pembayaran hasil layanan Jasa Konstruksi, termasuk di dalamnya jaminan atas pembayaran

$>$ Wanprestasi, memuat ketentuan tentang tanggung jawab dalam hal salah satu pihak tidak melaksanakan kewajiban sebagaimana diperjanjikan

> Penyelesaian perselisihan, memuat ketentuan tentang tata cara penyelesaian perselisihan akibat ketidaksepakatan

$>$ Pemutusan Kontrak Kerja Konstruksi, memuat ketentuan tentang pemutusan Kontrak Kerja Konstruksi yang timbul akibat tidak dapat dipenuhinya kewajiban salah satu pihak

$>$ Keadaan memaksa, memuat ketentuan tentang kejadian yang timbul di luar kemampuan para pihak yang menimbulkan kerugian bagi salah satu pihak

$>$ Kegagalan bangunan, memuat tentang ketentuan tentang kewajiban Penyedia Jasa dan/atau Pengguna Jasa atas kegagalan bangunan dan jangka waktu pertanggungjawaban kegagalan bangunan

> Perlindungan pekerja, memuat ketentuan tentang kewajiban para pihak dalam pelaksanaan kewajiban dalam pelaksanaan keselamatan dan kesehatan kerja serta jaminan sosial

> Perlindungan terhadap pihak ketiga selain para pihak dan pekerja, memuat kewajiban dalam hal terjadi suatu peristiwa yang menimbulkan kerugian atau menyebabkan kecelakaan dan/atau kematian

$>$ Aspek lingkungan, memuat kewajiban para pihak dalam pemenuhan ketentuan tentang lingkungan

$>$ Jaminan atas resiko yang timbul dan tanggung jawab hukum kepada pihak lain dalam pelaksanaan pekerjaan konstruksi akibat kegagalan bangunan

$>$ Pilihan penyelesaian sengketa konstruksi.

Kebebasan para pihak untuk menentukan klausa dalam perjanjian karena hukum perjanjian menganut asas terbuka. Gunawan Widjaja memberi pengertian tentang asas terbuka yaitu : 
Setiap orang bebas untuk membuat perjanjian atau bersepakat tentang segala hal, dalam bentuk apapun juga, dengan siapa saja, mengenai suatu benda tertentu selama dan sepanjang:

1. Perjanjian atau kesepakatan tersebut berada dalam lapangan bidang hukum dimana mereka dimungkinkan untuk berjanji atau bersepakat

2. Tidak bertentangan dengan undang-undang, kesusilaan, dan ketertiban umum, yang berlaku dalam masyarakat di mana kesepakatan atau perjanjian tersebut dibuat dan/atau dilaksanakan. ${ }^{9}$

Para pihak dapat menentukan klausul perjanjian yang dapat dicantumkan oleh para pihak dalam memilih untuk penyelesaian sengketa yaitu penyelesaian secara litigasi atau non-litigasi.

Untuk non-litigasi, para pihak dapat memilih penyelesaian sengketa melalui arbitrase atau alternatif penyelesaian sengketa di luar pengadilan yang lain, khususnya penyelesaian sengketa melalui arbitrase.

Dari hasil Studi Dokumen diatas terdapat beberapa kontrak kerja konstruksi yang mengalami permasalahan mengenai sengketa kontrak kerja konstruksi antara lain :

1. Terlambatnya waktu pelaksanaan proyek yang tidak sesuai dengan "Time Schedule" Rencana.

2. Adanya kekurangan volume pelaksanaan proyek konstruksi

3. Adanya perubahan pada Lokasi pelaksanaan proyek

Penyelesaian sengketa konstruksi ini melalui melalui musyawarah, mediasi, konsiliasi dalam hal penyelesaian perselisihan melalui perdamaian tidak tercapai, maka penyelesaian perselisihan tersebut dapat dilakukan melalui Arbitrase ( Penyelesaian di luar pengadilan ).

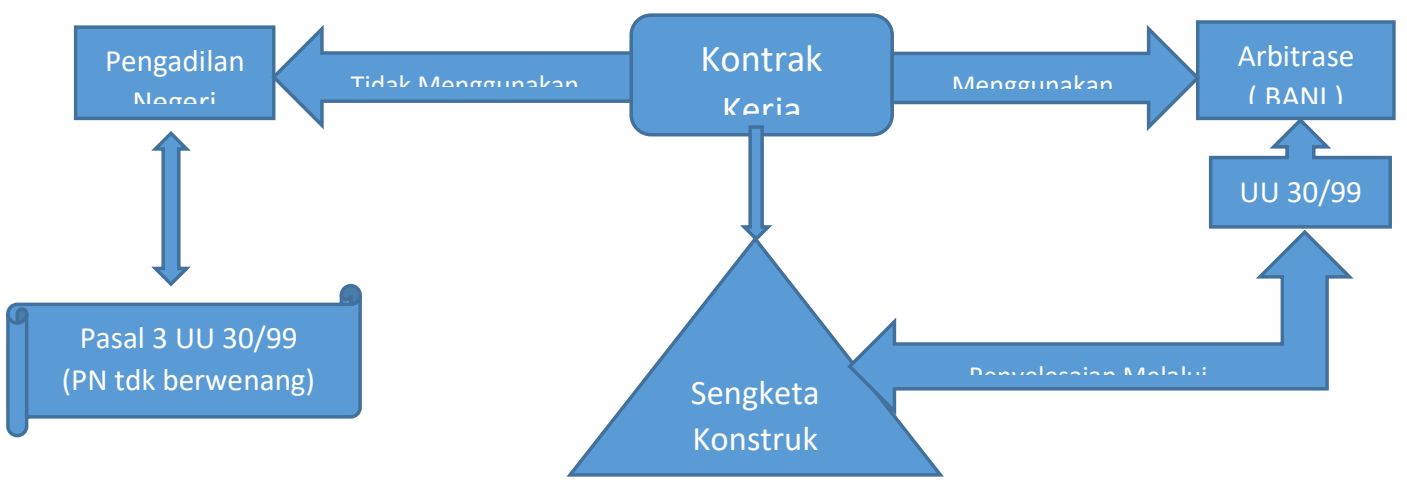

Gambar D.1. Alur Konsekuensi Kontrak Kerja Konsturksi Menggunakan / Mencantumkan Klausa Arbitrase ${ }^{10}$

\footnotetext{
${ }^{9}$ Gunawan Wijaya, Seri Hukum Bisnis Memahami Prinsip Keterbukaan (Aanvullend Recht) dalam Hukum Perdata, Jakarta: Rajagarfindo Persada, 2006.hlm. 300-301.

${ }^{10}$ Sumber: Data diolah dan dianalisis oleh peneliti
} 
Dalam merumuskan Konsekuensi Kontrak Kerja Konstruksi Pada Proyek Pemerintah Menggunakan Atau Mencantumkan Klausa arbitrase di Pasal 1 ayat 1 UU No. 30 Th 1999 tentang arbitrase \& alternatif penyelesaian sengketa ( APS ) pengertian arbitrase ialah cara menyelesaikan permasalahan sengketa perdata di luar pengadilan umum berdasarkan surat perjanjian arbitrase yang dituangkan tertulis oleh pihak I dan Pihak II yang bersengketa.

Hal ini sama dengan Teori Pembangunan Generasi I yang dikemukakan oleh "Prof. Mochtar Kusumaatmadja," yaitu Hukum adalah Suatu Alat untuk menjaga ketertiban di masyarakat. Melihat dari fungsinya sifat hukum pada dasarnya adalah Konservatif mempunyai arti hukum bersifat menjaga dan mempertahankan apa yang sudah di capai. Fungsi demikian dibutuhkan pada seluruh masyarakat, antara lain masyarakat yang sedang dan akan membangun, karena disinipun terdapat hasil yang tetap di jaga, dilindungi dan diamankan. Oleh Karena itu didalam teori pembangunan ini sudah jelas bahwa penegak hukum harus tetap menjalankan perintah undang - undang untuk tidak ikut campur dalam mengadili suatu sengketa kontrak kerja konstruksi yang sudah mencantumkan klausa arbitrase kedalam dokumen kontrak, sehingga penegak hukum dalam hal ini pengadilan tidak mempunyai wewenang dalam mengadili permasalahan terhadap para pihak yang sudah melakukan perjanjian arbitrase. Pemikiran lama mengenai hukum menitik beratkan manfaat untuk menjaga ketertiban dalam arti statis, dan mengutamakan sifat konservatif terhadap hukum. Berpendapat hukum tidak bisa melakukan hal yang penting untuk sebuah pembaruan. ${ }^{11}$

\section{Pembatalan putusan arbitrase pada kontrak konstruksi proyek pemerintah oleh Pengadilan Negeri}

Ada beberapa Perbedaan penyelesaian di BANI dengan penyelesaian sengketa pada pengadilan negeri antara lain:

1. Arbitrase tidak berlandaskan yuridis formal tetapi berlandaskan kebenaran dan kepatutan.

2. Keahlian dan kredibilitas yang dimiliki seorang arbiter harus melihat terhadap kwalitas yang layak untuk di andalkan, sehingga seorang arbiter yang adil dan tidak memihak terhadap siapapun. ${ }^{12}$

Pihak - pihak yang telah menentukan penyelesaian suatu sengketa melalui arbitrase boleh memilih lembaga yang akan membantu menyeselaikan sebuah sengketa konstruksi yaitu Badan Arbitrase Nasional Indobesia ( BANI ).

Dalam Pandangan peneliti supaya permsalahan sengketa / perselisihan dilakukan pemeriksaan, penyelidikan dan pemutusannya kepada BANI, maka para pihak harus menuangkan klausa arbitrase kedalam Kontrak Kerja Konstruksi. Apapu permsalahan sengketa yang muncul dari kesepakatan ini, Badan Arbitrase Nasional Indonesia ( BANI ) yang akan menyelesaikandan memutuskan menurut

\footnotetext{
${ }^{11}$ Mochtar Kusumaatmadja, Konsep-Konsep Hukum Dalam Pembangunan (Kumpulan Karya Tulis), Bandung: Alumni, 2002, hlm. 14

${ }^{12}$ Eman Suparman, Arbitrase \& dilema Penegakan Keadilan, Jakarta: PT. Fikahati Aneska, 2012, hlm. 10
} 
peraturan dan Perundang - undangan yagng berlaku. Keputusannya mengikat terhadap kedua belah pihak yang bersengketa.

Walaupun belum ada peraturan perundang-undangan yang secara spesifik dan komprehensif mewajibkan untuk mencantumkan Klausa Arbitrase dalam setiap Kontrak Kerja Kontruksi akan tetapi dapat digunakan sebagai landasan kebijakan untuk mencantumkan Klausa Arbitrase ke dalam Kontrak Kerja Konstruksi antara lain :

1. "UU No. 18 Tahun 1999 Tentang Jasa Konstruksi"

2. "UU No. 2 Tahun 2017 Tentang Jasa Konstruksi"

3. "UU No. 30 Tahun 1999 Tentang Arbitrase dan Alternatif Penyelesaian Sengketa."

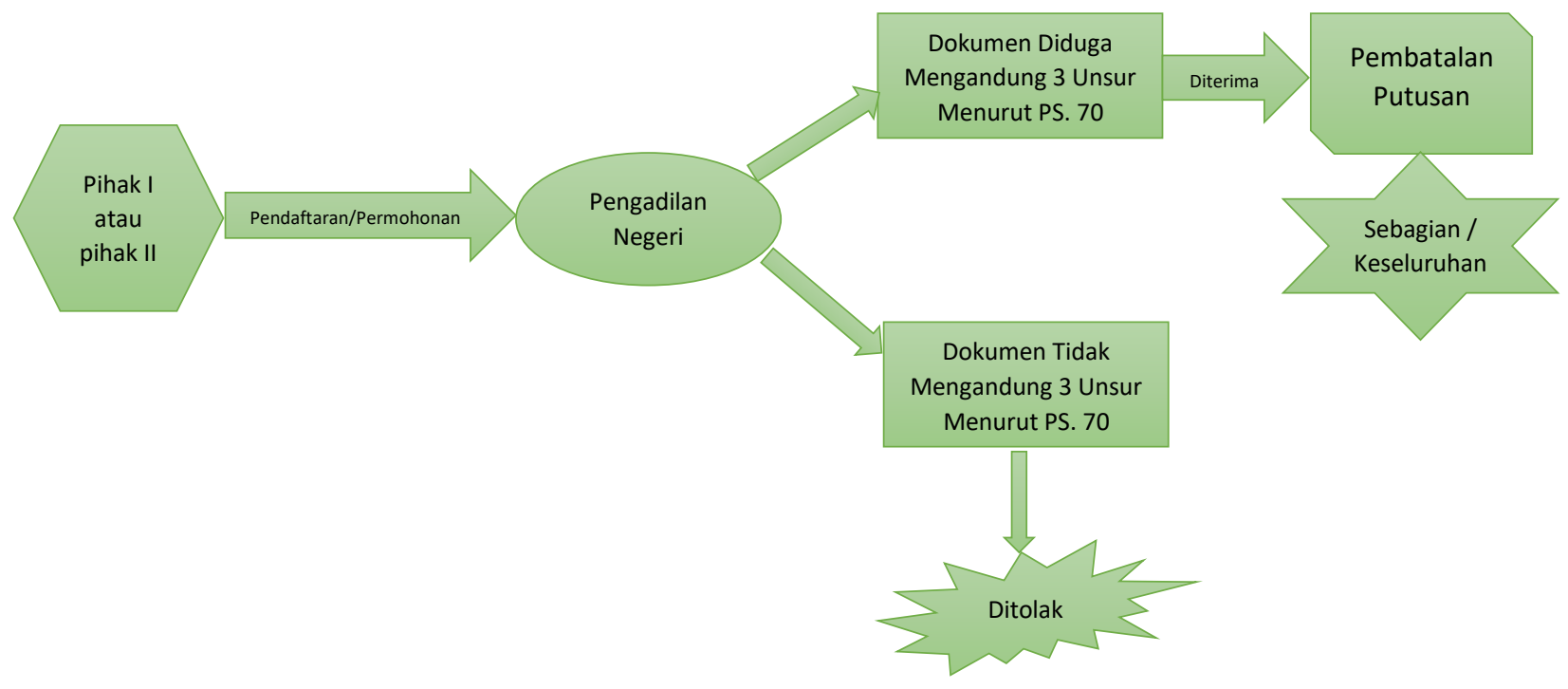

\section{Gambar D.2. Alur Pembatalan Putusan Arbitrase Oleh Pengadilan Negeri ${ }^{13}$}

Pengadilan yang ada di Indonesia belum sepaham dalam memberikan putusan serta belum memahami ketentuan pada Pasal 70 dalam memastikan putusan arbitrase bagi pihak I dan Pihak II untuk mengajukan surat permohonan pembatalan jika keputusan arbitrase diduga mengandung bagian - bagian dibawah ini antara lain :

1. Dokumen dan surat - surat yang diberikan dalam pemeriksaan ternyata palsu dan dinyatakan palsu.

2. Adanya Dokumen yang disembunyikan oleh pihak lawan dan Dokumen yang bersifat menentukan setelah keputusan diambil.

3. Hasil Putusan yang tidak adil, karena adanya tipu muslihat dari salah satu pihak.

${ }^{13}$ Sumber: Data diolah dan dianalisis oleh peneliti 
Dari ketentuan diatas, sudah jelas dalam Pasal 70 hanya mengatur alasan yang boleh digunakan bagi para pihak yang bersengketa dalam mengajukan permohonan pembatalan terhadap putusan arbitrase. Alasan yang digunakan harus bersifat "optional atau fakultatif". Oleh Karena sifatnya yang optional tersebut, maka "pada Pasal 70 UU No. 30 Tahun 1999 mengenai Arbitrase dan Alternatif Penyelesaian Sengketa ( APS ), bermaksud memberikan sebuah perlindungan terhadap hukum kepada pihak - pihak yang terlibat langsung dalam proses arbitrase, yang merasa putusan dari arbitrase yang berikan terhadapnya tidak adil dan terdapat dugaan pemalsuan, penyembunyian fakta / dokumen atau tipu muslihat. Ternyata Pada "Pasal 70 UU No. 30 / 1999 tidak mengatur alasan mahkamah boleh membatalkan terhadap keputusan arbitrase. Ketentuan Pasal 70 tidak menyebutkan alasan yang bisa di pakai oleh pengadilan untuk memeriksa, menolak dan mengabulkan permohonan pembatalan terhadap putusan Arbitrase. Jadi menurut peneliti, pengadilan dalam menjalankan kewenangan dan fungsinya untuk menerima dan memeriksa permohonan membatalkan terhadap putusan arbitrase berbeda dengan kewenangan dan fungsi pengadilan untuk melaksanakan ( eksekusi ) mengenai putusan arbitrase yang telah diputuskan. Pengadilan harus berperan administrative untuk memeriksa sebuah permohonan keputusan arbitrase, dan pengadilan akan bersikap yudikatif untuk memeriksa sebuah permohonan untuk pembatalan keputusan arbitrase. Jadi menurut peneliti, kepada pihak yang menang di dalam sengketa arbitrase hendaknya dipanggil untuk memberikan keterangannya oleh pengadilan, selain itu juga tentunya pengadilan mendengarkan keterangan dari pihak arbiter yang mengeluarkan keputusan arbitrase itu. Dalam wewenang pengadilan untuk memeriksa permohonan pembatalan terhadap putusan arbitrase mempunyai kewenangan yang sangat luas dibandingkan dengan memeriksan sebuah permohonan untuk pelaksanaan putusan arbitrase karena pengadilan hanya bisa melaksanakan fungsi control nya saja.

Menurut peneliti, permohonan pengajuan pembatalan terhadap sebuah keputusan arbitrase harus berdasarkan beberapa alasan yang telah diungkapkan di dalam “pasal 70 UU no. 30 / 1999 mengenai arbitrase dan APS”. Kepada Pihak yang menajukan permohonan pembatalan hendaknya bisa memberikan bukti yang akurat bahwa terhadap putusan arbitrase telah mengandung unsur - unsur pemalsuan, tipu muslihat, atau menyembunyikan fakta - fakta seperti surat - sruat / dokumen terkait sengekta tersebut. Hal yang sering menjadi perdebatan didalam prakteknya mengenai maksud kata pemalsuan, tipu mislihat atau menyembunyikan fakta - fakta seperti surat - surat / dokumen, karena kurangnya penjelasan sebagaimana yang dimaksudkan di dalam Pasal 70 UU no, 30 / 1999 tentang arbitrase dan APS . Oleh karena itu peneliti kurang setuju pendapat yang mengatakan sebuah Putusan oleh Arbitrase di duga adanya faktor kata pemalsuan, menyembunyikan fakta - fakta seperti surat - surat / dokumen atau tipu muslihat, oleh karena itu peneliti mengutip ketentuan keterangan Pasal 70 UU no. 3 / 199 mengenai Arbitrase dan APS berikut ini: 
"Alasan-alasan permohonan pembatalan yang disebut dalam pasal ini harus dibuktikan dengan putusan pengadilan. Apabila pengadilan menyatakan bahwa alasan-alasan tersebut terbukti atau tidak terbukti, maka putusan pengadilan ini dapat digunakan sebagai dasar pertimbangan bagi hakim untuk mengabulkan atau menolak permohonan."

Peneliti mengamati didalam prakteknya terdapat beberapa yang mengatakan tentang dugaan adanya unsur pemalsuan, tipu mislihat atau menyembunyikan fakta - fakta seperti surat - surat / dokumen, yang akan menjadi alasan pihak yang mengajukan permohonan pembatalan wajib dibuktikan dengan suatu putusan pengadilan. Para Pihak biasanya berpendapat berdasarkan pada kalimat awal yang tertuang di dalam penjelasan pasal 70 UU no. 30 / 1999 mengenai Arbitrase dan APS dan tidak melihat dan memahami maksud dari kalimat selanjutnya. Sedangkan jika kalimat selanjutnya dibaca dan dipahami, Para Pihak akan sulit mempertahankan Pendapatnya. Dasar bagi hakim dalam mempeertimbangkan putusan untuk mengabulkan atau menolak permohonan pihak yang bersengketa terhadap ketentuan tersebut maka keputusan ketua pengadilan dianggap tidak absolut di syaratkan oleh pengadilan untuk menerima atau menolak sebuah permohonan pembatalan terhadap keputusan arbitrase tersebut.

Dengan ini peneliti berpendapat, kata dugaan disama artikan dengan istilah persangkaan paling sering di pakai pada hukum acara perdata, oleh karena itu peneliti perlu memberi tahukan bahwa alasan persangkaan yang boleh mendukung untuk mengabulkan permohonan pembatalan suatu putusan arbitrase harus terdapat fakta - fakta yang sah sebagai alasan pengabulan. Jika terdapat fakta mengenai arbiter terdapat melakukan kelalaian dalam melaksanakan tugas atau wewenangnya yang telah diberikan menurut Kontrak arbitrase, Oleh karena ini kelalaian tersebut masuk kedalam kategori penipuan atau tipu Muslihat. Sebenarnya "Adagium hukum" sudah mengatakan "Magna culpa dolus est. Great neglect is equivalent to fraud" yang bermakna, kelalaian yang besar sama artinya dengan penipuan atau tipu muslihat.

Suatu Pelanggaran mengenai ketertiban umum (public policy, public order) akan dianggap yang lebih berat dari pada alasan yang terdapat didalam pasal 70 UU no. 30 / 1999 mengenai Arbitrase dan APS . Beberapa kasus pengadilan yang ada di Indonesia sama halnya dengan pengadilan yang ada Negara lain di seluruh dunia, yang menyatakan Pelanggaran Hukum terhadap terhadap ketentuan yang simatnya memaksa "( Mandatory Rulles Of Law )" adalah suatu pelanggaran mengenai Ketertiban Umum. Mengenai hal ini, ada beberapa ketentuan yang terdapat didalam undang - undang arbitrase yang telah dianggap sifatnya mandatory ( Memaksa dan Bagaimanapun tidak dapat dikesampingkan ).

Hasil analisis pembahasan tersebut diatas mengukuhkan Teori Hukum Pembangunan oleh Prof Mochtar Kusumaatmadja, adalah sebuah Teori Hukum yang muncul dari kondisi masyarakat Indonesia yang berlandaskan Pancasila. Teori Hukum Pembangunan pada dasarnya mucul dan berkembang sangat tepat untuk diterapkan kepada masyarakat Indonesia ( dalam hal ini Pelaku Jasa Konstruksi ). Teori Hukum Pembangunan oleh Prof. Mochtar Kusumaatmadja 
pada umumnya diaktualisasikan terhadap kondisi masyarakat Indonesia dan pada khususnya kondisi penegakan hukum akan bersinergi yang timbal balik secara selaras. ini dapat dibuktikan melalui penyelesaian sengketa arbitrase bahwa pengadilan tidak boleh membatalkan suatu putusan arbitrase sehingga aparat penegak hukum seperti pengadilan dapat bersinergi dengan lembaga lembaga peradilan lainnya yang salah satunya lembaga Arbitrase. Teori Hukum Pembangunan oleh Prof. Mochtar Kusumaatmadja ini akan menjadikan acuan pertama serta menempatkan hukum yang dapat berperan aktif dan dinamis sebagai dinamisator maupun katalisator untuk sarana pembaharuan seluruh masyarakat Indonesia dalam hal ini Pelaku Jasa Konstruksi.

3. Sengketa kontrak kerja konstruksi mempunyai unsur pidana menurut Pihak Ketiga, sedangkan dalam pandangan Para Pihak masuk dalam kategori kontrak atau ranah perdata

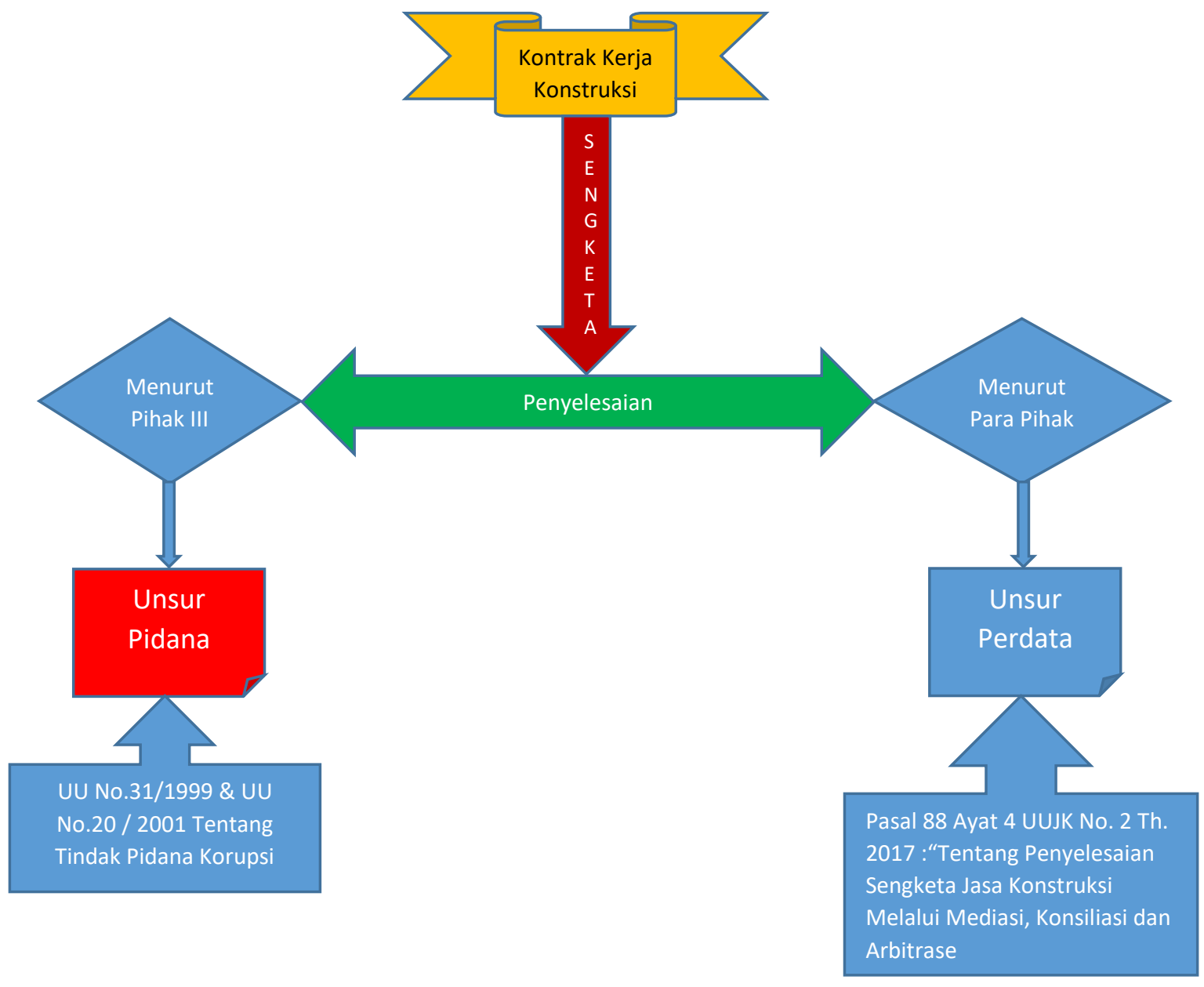

Gambar D.3. Alur Perdebatan Penyelesaian Sengketa Kontak Kerja Konstruksi ${ }^{14}$

${ }^{14}$ Sumber: Data diolah dan dianalisis oleh peneliti 
Aparat Hukum dipandang belum beberapa memahami dengan baik yang mengenai masalah kontrak kerja konstruksi. Dilihat dari beberapa kasus sengketa kontrak kerja konstruksi, aparat hukum selalu membawa permasalahan sengketa kontrak kerja konstruksi ke ranah peradilan pidana. Oleh karena itu para penyedia jasa konstruksi diancam "Undang - Undang Nomor 31 Tahun 1999" sebagaimana telah diubah dengan "Undang - Undang Nomor 20 Tahun 2001 pasal 2 dan Pasal 3 Kitap Undang - Undang Hukum Pidana Tentang Pemberantasan Tindak Pidana Korupsi", khususnya "Pasal 2 Ayat 1 tentang Tindak Pidana Korupsi".

Sesungguhnya kontrak kerja konstruksi merupakan ranah hukum privat, yaitu ranah hukum perdata, karena yang terikat kontrak kerja konstruksi hanya beberapa pihak. Mekanisme penyelesaian hukum privat berbeda dengan mekanisme penyelesaian hukum pidana. Oleh Karena itu, aparat hukum perlu memperbaiki cara pandang mengenai permasalahan kasus sengketa kontrak kerja konstruksi. Karena, pemahaman aparat hukum, terutama di daerah, masih terbatas pada KUHP dan perundang-undangan Tipikor.

Menurut peneliti, permasalahan dengan sengketa Kontrak Kerja Konstruksi lebih sering dialami dalam bentuk kekurangan Volume Pekerjaan, Keterlambatan dalam Pelaksanaan dan Kegagalan Konstruksi Bangunan, yang dilakukan oleh penyedia jasa konstruksi, Penyelesaian permasalahan sengketa dengan kesepakatan antara kedua belah pihak yang dituangkan di dalam kontrak kerja konstruksi yang disepakati para pihak. Didalam kontrak juga mengatur mekanisme penyelesaian sengketa, oleh karena itu tidaklah tepat jika ranah hukum pidana dibawa untuk menyelesaikan masalah ini.

Jika terjadi wanprestasi, Aparat Hukum selalu menganggap hal itu termasuk ke dalam unsur merugikan keuangan negara. sebenarnya permasalahan sengketa antara kedua belah pihak ini jelas bersifat keperdataan. Oleh Karena itu, masalah kontrak kerja konstruksi harus dilakukan sesuai mekanisme dan atuaran yang terdapat di dalam kontrak. Seharusnya permasalahan sengketa kontrak kerja konstruksi diselesaikan melalui jalur perdata.

Sedangkan mengenai unsur kerugian negara yang terdapat pada "pasal 2 UU No. 31 Tahun 1999 Tentang Pemberantasan Tipikor" jika adanya unsur melawan hukum. Terhadap unsur melawan hukum Aparat Penegak Hukum harus mencari bukti jika memang benar kesalahan pada sengketa kontrak kerja konstruksi memang di sengaja. Jika tidak maka pasal tipikor tidak boleh digunakan untuk menjerat pelaku jasa konstruksi.

"Undang - Undang No. 2 Tahun 2017 Tentang Jasa Konstruksi Lembaran Negara Republik Indonesia Nomor 11 dan Tambahan Lembaran Negara Republik Indonesia Nomor 6018 Tentang Jasa Konstruksi" ternyata memiliki materi muatan yang jauh lebih banyak ketimbang UU sebelumnya. Selain itu, UU Jasa Kontruksi terbaru ini memiliki banyak perbedaan dan lebih terperinci dan lebih banyak melibatkan pemerintah dalam usaha jasa kontruksi.

Diawali dengan musyawarah mufakat terlebih dahulu dalam penyelesaian sengketa. Jika tidak tercapai, pilihan penyelesaian sengketa mesti sesuai kontrak kerja konstruksi yang disepakati sebelumnya. Seperti, mediasi, arbitrase, 
konsiliasi, dan melalui pembentukan Dewan Sengketa.

Dalam hal kegagalan bangunan konstruksi yang disertai dengan kontrak kontruksi yang disetujui kedua belah pihak, salah satu pihak dapat mengadukan kepada menteri. Setelah menerima laporan terkait kegagalan bangunan kontruksi, Menteri akan menetapkan peniliai ahli dalam hal kegagalan bangunan. "Setelah laporan penilai ahli, maka ditentukan pihak-pihak mana saja yang bertanggung jawab.

Hasil analisis pembahasan tersebut diatas mengukuhkan teori Hukum Pembangunan Prof. Mochtar Kusumaatmadja yang mengatakan bahwa defenisi hukum dalam arti seluas luasnya, tidak hanya norma - norma dalam kaidahkaidah untuk mengatur kehidupan manusia di dalam masyarakat dalam hal ini pelaku konstruksi, dan mencakup juga lembaga / institusi dan proses yang menciptakan berlakunya norma - norma dan kaidah-kaidah itu dalam kenyataan. Oleh karena para aparat hukum harus bisa memilah antara ranah hukum perdata dan ranah hukum pidana karena dalam penyelesaian sengketa kontrak kerja konstruksi sudah jelas masuk ke ranah perdata menurut undang - undang jasa konstruksi No. 2 Tahun 2017 Tentang Jasa Konstruksi. Agar fungsi dan peranan hukum dapat dilaksanakan secara optimal dalam pembangunan nasional, maka hukum tidak semata - mata dipandang sebagai wujud dari komitmen politik melainkan harus dipandang sebagai sarana untuk mengubah sikap dan cara berpikir dan perilaku aparatur birokrasi dan masyarakat bersama-sama (dalam hal ini Pelaku Konstruksi).

\section{E. Kesimpulan}

Berdasarkan hasil penelitian dan pembahasan pada bab sebelumnya, maka dapat disimpulkan beberapa hal sebagai berikut :

1. Akibat hukum pencantuman klausa arbitrase dalam kontrak kerja konstruksi bagi pihak - pihak yang akan menyelesaikan permasalahan sengketa melalui arbitrase, pengadilan negeri tidak berwenang untuk mengadili seperti yang sudah diatua di dalam Pasal 3 dan Pasal 11 UU No. 30 / 1999 mengenai Arbitase dan APS.

2. Pengadilan dalam menjalankan kewenangan dan fungsinya untuk menerima dan memeriksa permohonan membatalkan terhadap putusan arbitrase berbeda dengan kewenangan dan fungsi pengadilan untuk melaksanakan ( eksekusi ) mengenai putusan arbitrase yang telah diputuskan. Pengadilan lebih berjiwa administrative dalam memeriksa permohonan putusan arbitrase, dan pengadilan akan bersikap Yudikatif untuk memeriksa permohonan pembatalan putusan arbitrase. Dalam wewenang pengadilan untuk memeriksa permohonan pembatalan terhadap putusan arbitrase mempunyai kewenangan yang lebih luas dibandingkan dengan memeriksa suatu permohonan pelaksanaan putusan arbitrase karena pengadilan hanya bisa melaksanakan fungsi kontrolnya saja.

3. Kontrak kerja konstruksi merupakan ranah hukum privat, yaitu ranah hukum perdata, karena yang terikat kontrak kerja konstruksi hanya beberapa pihak. Mekanisme penyelesaian hukum privat berbeda dengan mekanisme penyelesaian hukum pidana. Oleh Karena itu, aparat hukum 
perlu memperbaiki cara pandang mengenai permasalahan kasus sengketa kontrak kerja konstruksi. Karena, pemahaman aparat hukum, terutama di daerah, masih terbatas pada KUHP dan perundang-undangan Tipikor. Karena itu, perlu adanya kesepahaman antara aparat hukum seperti kepolisian, kejaksaan dan KPK untuk memperbaiki pemahaman dalam menyikapi permasalahan sengketa kontrak kerja konstruksi. Pemahaman aparat hukum seperti kejaksaan, kepolisian dan KPK, masih terbatas pada KUHP dan UU tentang Tipikor, Undang-Undang No. 2 Tahun 2017 tentang Jasa Konstruksi sebagai pengganti UU No. 18 Tahun 1999 tentang Jasa Konstruksi ternyata memiliki materi muatan yang jauh lebih banyak ketimbang UU sebelumnya. Selain itu, UU Jasa Kontruksi terbaru ini memiliki banyak perbedaan dan lebih terperinci dan lebih banyak melibatkan pemerintah dalam usaha jasa kontruksi. 


\section{DAFTAR PUSTAKA}

\section{Buku}

Badrulzaman, M.D, KUH Perdata, Buku III, Hukum Perikatan dengan Penyelesiannya, Penerbit Alumi, Bandung, 1993.

Eman Suparman, Arbitrase \& dilema Penegakan Keadilan, Jakarta: PT. Fikahati Aneska, 2012.

Feydy Bonenehu, Analisis Klausul Kontrak, Fakultas Teknik Universitas Indonesia, 2008.

Hamid Shahab, Aspek Hukum Dalam Sengketa Bidang Konstruksi, Jakarta: Djambatan, 1996.

Gunawan Wijaya, Seri Hukum Bisnis Memahami Prinsip Keterbukaan (Aanvullend Recht) dalam Hukum Perdata, Jakarta: Rajagarfindo Persada, 2006.

J. Satrio, Hukum Perikatan, Perikatan Yang Lahir Dari Perjanjian, Buku I, Bnandung: Citra Aditya Bakti, 1955.

Lili Rasjidi dan Ida Bagus Wiyasa Putra, Hukum Sebagai Suatu Sistem, Bandung: Mandar Maju, 2003.

Mochtar Kusumaatmadja, Konsep-Konsep Hukum Dalam Pembangunan (Kumpulan Karya Tulis) Bandung: Alumni, 2002

Mochtar Kusumaatmadja, Hukum Masyarakat dan Pembinaan Hukum Nasional, Bandung: Binacipta, 1995

Mochtar Kusumaatmadja, Fungsi dan Perkembangan Hukum dalam Pembangunan Nasional, Bandung: Bina Cipta, tanpa tahun

Mochtar Kusumaatmadja, Pembinaan Hukum Dalam Rangka Pembangunan Nasional, Bandung: Penerbit Binacipta, 1986

Otje Salman dan Eddy Damian (ed), Konsep-Konsep Hukum dalam Pembangunan dari Mochtar Kusumaatmadja, Jakarta: PT.Alumni, Bandung, 2002

Suyud Margono, ADR dan Arbitrase Proses Pelembagaan dan Aspek Hukum, Jakarta: Ghalia Indonesia, 2000.

Shahab, H, Menyingkap dan Meneropong Undang-undang Arbitrase No. 30 Tahun 1999 dan Penyelesaian Alternatif serta Kaitannya dengan UU Jasa Konstruksi No. 18 Tahun 1999 dan FIDIC., Jogjakarta: Liberty, 2000

Shidarta, Karakteristik Penalaran Hukum Dalam Konteks Ke- Indonesiaan, Jakarta: CV. Utomo, 2006

Sjachran Basah, Perlindungan Hukum Terhadap Sikap Tindak Administrasi 
Negara, Jakarta: Alumni, Bandung, 1992

Standar Dokumen Pengaadaan Secara Elektronik, Pengadaan Pekerjaan Konstruksi, LKPP, BAB X

Subekti dan Tjitrosudibio, Kitab Undang-undang Hukum Perdata (terjemahan dari Burgerlijk Wetboek), Cetakan Ketigapuluh, Jakarta: Penerbit Pradnya Paramita, 1999.

Peter Mahmud Marzuki, Penelitian Hukum, Jakarta: Kencana, 2007.

Peter Mahmud Marzuki, Penelitian Hukum, Jakarta: Prenada Media Group, Cetakan ke-6, 2010.

Poerdyatmono, B, Sengketa Pelaksanaan Kontrak Kerja Konsultan Pengawas Konstruksi, Skripsi S-1 llmu Hukum, Fakultas Hukum, Universitas Sunan Giri, Surabaya (tidak dipublikasikan), 2003

Poerdyatmono, B, Sengketa Jasa Konstruksi sebagai Akibat Terbitnya Beschikking dan Pelaksanaan Kortverban Contract : Tinjauan Aspek Hukum Manajemen Proyek, Prosiding Seminar Nasional VII, Program Studi Magister Manajemen Teknologi, Program Pascasarjana Institut Teknologi 10 November Surabaya, 2008.

Tony Budidjaja, Public Policy as Grounds for Refusal of Recognition and Enforcement of Foreign Arbitral Awards in Indonesia, Jakarta : Tatanusa, 2002.

\section{Artikel Jurnal}

Bambang Poerdyatmono, "Alternatif Penyelesaian Sengketa Jasa Konstruksi". Jurnal Teknik Sipil, Vol. 8, No. 1, 2007

BN Marbun, Kamus Politik, Pustaka Sinar Harapan, 2002.

Sujayadi, "Patologi dalam Arbitrase Indonesia", Jurnal Hukum Acara Perdata, Vol. 1, No. 2, 2015

Poerdyatmono, B, Asas Kebebasan Berkontrak (Contractvrijheid Beginselen) dan Penyalahgunaan Keadaan (Misbruik van Omstandigheden) pada Kontrak Jasa Konstruksi, Jurnal Teknik Sipil, Program Studi Teknik Sipil, Fakultas Teknik, Universitas Atmajaya, Jogjakarta, Volume 6 No. 1. 2005.

\section{Peraturan Perundang-undangan}

Undang-Undang No. 18 Tahun 1999 Tentang Jasa Konstruksi Lembaran Negara Republik Indonesia Nomor 54 dan Tambahan Lembaran Negara Republik Indonesia Nomor 3833 
Undang-Undang Nomor 30 Tahun 1999 Tentang Arbitrase dan Alternatif Penyelesaian Sengketa, Lembaran Negara Republik Indonesia Tahun 1999 Nomor 138 dan Tambahan Lembaran Negara Republik Indonesia Nomor 3872

Undang-Undang No. 2 Tahun 2017 Tentang Jasa Konstruksi Lembaran Negara Republik Indonesia Nomor 11 dan Tambahan Lembaran Negara Republik Indonesia Nomor 6018

Peraturan Pemerintah Republik Indonesia Nomor 28 Tahun 2000 tentang Usaha dan Peran Masyarakat Jasa Konstruksi

Peraturan Pemerintah Republik Indonesia Nomor 29 Tahun 2000 tentang Penyelenggaraan Jasa Konstruksi

Peraturan Pemerintah Republik Indonesia Nomor 30 Tahun 2000 tentang Penyelenggaraan Pembinaan Jasa Konstruksi 